JACEK RUDEWICZ

University of Szczecin, Poland

\title{
Entrepreneurship in Slum Dwellers: Social Inclusion and the 'Right to a City'
}

\begin{abstract}
According to UN data, the global urbanisation rate is currently 55\%, and in 2050 it is expected to reach $68 \%$. The leading causes of urban population growth are economic development and polarisation, agricultural change, political instability, climate change and population growth. Additionally, in many countries local authorities are unable to provide adequate living conditions for the newcomers. The scale of the phenomenon of informal urbanism and slums has been known for decades and is still high. Slum dwellers face many barriers on their way to improving living conditions and top-down attempts to improve them have proved ineffective, e.g. mass social housing, the fight against crime. The paradigm of treating slum dwellers, however, as low-skilled, demoralised, deprived of all kinds of capital and any sign of entrepreneurship is changing. The paradigm shift in aid to slum dwellers is based on bottom-up stimulation of their entrepreneurial attitudes, social inclusion and activation. The article has two main objectives, the first one - descriptive and cognitive - to develop a background and geographical synthesis of information on the phenomenon of global slum formation based on the most recent data. The second objective is an attempt to demonstrate the legitimacy of changing the approach and activating the entrepreneurship of slum dwellers.
\end{abstract}

Keywords: cities; creativity; entrepreneurship; poverty; slums; urbanisation; urban studies; the Third World

Received: 11 November 2019

Accepted: 20 July 2020

\section{Suggested citation:}

Rudewicz, J. (2020). Entrepreneurship in Slum Dwellers: Social Inclusion and the 'Right to a City'. Przedsiębiorczość - Edukacja [Entrepreneurship - Education], 16(2), 318-333. doi: 10.24917/20833296.162.25

\section{Introduction}

The motivation for this article and the basis for its approach was the reading of international reports and books on informal urbanism, the latter being Radical Cities: Across Latin America in Search of a New Architecture by Justin McGuirk and Rebel Cities: From 
the Right to the City to the Urban Revolution by David Harvey. On this basis, the main objectives of the article were defined. The first goal was to determine the quantitative scale of informal urbanisation, change over time and geographical synthesis according to macro-aggregation of the areas where it is found, i.e. mainly in the so-called Global South. The data used to achieve this goal concern the years 1990-2014 and come from the publicly available UN database, Habitat. The second goal was to try to demonstrate the legitimacy of changing the approach and way of thinking and demonstrate the entrepreneurial attitudes of slum dwellers. This goal was achieved through analysing case studies based on a review of press releases and academic articles.

The text of the article is divided into four parts. The first discusses the question of the nature of slums and who their inhabitants are. It presents the theoretical foundations for the slum phenomenon and describes the largest slums in the world. The second, quantitative, part presents changes in the number of poor city residents against global urbanisation over time through diagrams and charts. The third part describes case studies according to place, person, and activity. In the fourth, a summary is made, and conclusions are drawn.

\section{What are slums, and who are their inhabitants?}

Slums are areas of cities inhabited by poor people, most often immigrants or newcomers from rural areas, workers employed in large investment projects, or specific ethnic populations, e.g. 'Amerindians'. Such areas are common in large agglomerations of developing countries (e.g. in Africa, Asia or South America). A slum is a general term, and the areas that bear this infamous name differ from each other in many respects concerning the origin, culture and religion of the inhabitants, the urban structure and type of building. Their genesis, as well as the differing political and economic background of their existence, also varies. Within one urban agglomeration, individual slums may differ from each other while, depending on the city, their spatial proportion and population vary. Remote sensing studies (Friesen et all., 2019) conducted in Cairo (Egypt), Cape Town (South Africa), Rio de Janeiro and São Paulo (Brazil), Caracas (Venezuela), Manila (Philippines), Mumbai (India) and Dhaka (Bangladesh), indicate that $84.6 \%$ range from just 0.001 to $0.1 \mathrm{~km}^{2}$. The parameters defining slum buildings include high density and small housing.

The typology of slums based on research in Cairo in 2003 (Understanding Slums...) indicates the existence of four types. For example, the most significant areas of nearly $50 \%$ of a city are occupied by 'A' slums, which are buildings in former agricultural areas, without building permits. These are partially formalised as they were legally sold to the new owners by farmers. This phenomenon had its roots in the 1960s when small agricultural areas on the outskirts of 'formal' Cairo began to be divided and sold to individual owners. The agricultural origin of these areas meant that the houses were built along irrigation canals, which became communication arteries. The streets in these developments are very narrow, about 2 to 4 meters wide, and the buildings are 7 to 10 meters high. There are no public or service spaces in these slums, and plots are usually small, around $80 \mathrm{~m}^{2}$. The buildings are mainly of reinforced concrete structure with walls of brick. Areas of this type suffer from enormous overpopulation. Interestingly, the buildings constructed illegally in the years following required the consent and regulations of local communities and payment for utilities. 
In turn, a type 'B' slum is typical not only for Cairo but for the entire Third World. These are built on public land, e.g. in desert areas where workers, soldiers and immigrants were allowed to settle. The government's negligence led to the development of illegal settlements, a completely informal process with no documentation or permission required. Settlers pay local taxes and for utilities, thus having access to electricity, but despite the illegal status of these areas, regulating their legality is not tricky. The housing conditions in this type of slum are worse than those in type ' $A$ '. Type ' $C$ ' are slums in the historic districts of cities, in their medieval fabric which, due to the impoverishment of the inhabitants and the influx of new ones, has deteriorated. Type ' $D$ ' consists of small downtown areas distributed in points ( $1 \%$ of urban area). Often these are tall buildings with an unclear legal status inhabited by low-income families; they tend to be demolished, and the residents evicted. The morphological characteristics of slums were also determined by a study done in Sao Paulo by the Brazilian Institute of Geography and Statistics (IBGE) as part of the 2010 Census. This census classified slums (favelas) as agglomerations of at least 51 shacks or 'houses' meeting the criteria for informal urbanisation. They have narrow, irregularly arranged roads, and uneven plots and shapes (Censo Demográfico $2010 \ldots, 2011)$.

The term 'slum' derives from British industrial cities in the $19^{\text {th }}$ century where crowded residential areas with a low standard of living occupied more than $60 \%$ of a city. Other terms in English for slums are 'shanty towns', 'squatter towns' (Gregory et al., 2009), and less often 'mushroom towns' or 'tent cities'. Those who live in slums are sometimes stigmatised in English as slum dwellers or squatters, in Africa as moskwota, in Mexico paracaidistas or colonos, in Brazil - favelados, in Chile and Argentina - ocupas. Workers from the countryside migrated to the developing cities in huge numbers, and life in these communities became the subject of research by Freidrich Engels in his work The Condition of the Working Class in England. Currently, neo-Marxists point to a contemporary slum transposition from the Global North to the Global South (Davis, 2006). The phenomenon of post-colonialism is essential here.

Cities with a colonial past were divided between European districts of a 'white city' and an impoverished, crowded 'native city'. Contemporary slums developed on the outskirts of megacities and their genesis can also be linked to the transnational circulation of capital and the economic effects of neoliberalism. For a long time now, slums have been places of exclusion and problems. Karl Marx saw in the slums a particular potential for a 'surplus army' in the class struggle (Davis, 2006) and currently this specific potential is used by politicians and social movements (Angotti, 2006). In studies in urban geography, it is written that slums are usually found on inhospitable terrain on the outskirts of cities occupying hilly areas, brownfields, floodplains, desert areas, landfills, empty buildings, areas overlooked or forgotten by developers and authorities. These informal neighbourhoods often have local names, such as barierada in Peru, favelas in Brazil, villas misérias in Argentina, or bario in Venezuela. Figure 1 presents a spatial model of the city in developing countries with a concentric shape, but with strips reaching into the centre. Distance from the city centre and workplaces, in the absence of infrastructure, is also a factor that has caused a decrease in the attractiveness of the outskirts of the city. In the case of cities such as Caracas, Bogota, Medellin and Rio de Janeiro, there is also the problem of steep slopes and the availability of land. 
Figure 1. The model of the city in developing countries

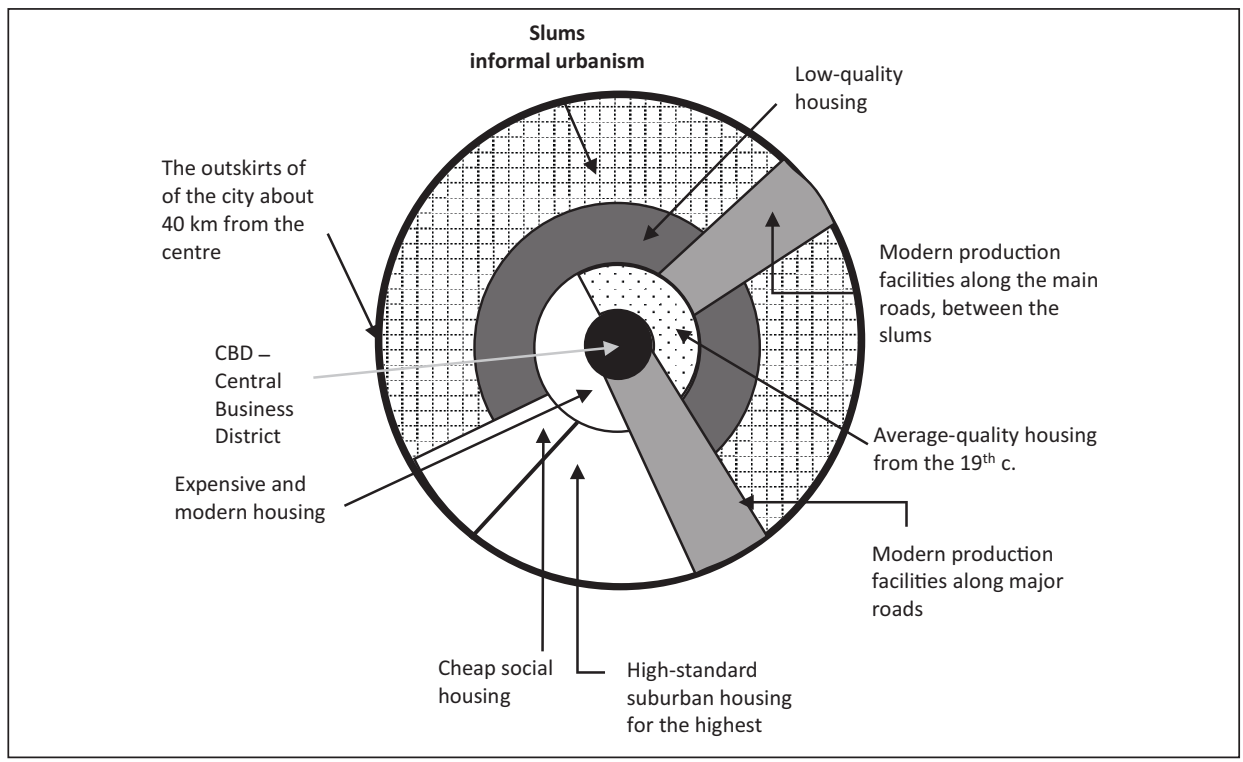

Source: author based on the Modern Dictionary of Geography Small, Ross, Witherick (2001: 204)

City centres of developing countries (Third World) often resemble those known from cities in highly developed countries. In central business districts (CBD), office buildings, hotels, service facilities, headquarters of global corporations, and modern complexes of high office buildings made of glass and steel are being built. These are places of consumption for foreigners and the middle class. However, these districts do not transfer naturally into the rest of the central city; very often they are adjacent to districts of poverty (Photo 1) and the poor are rarely allowed out of these neighbourhoods by security and fencing.

Materials used to build housing and shacks include corrugated iron sheets, wooden boards and cardboard; in many slums, clay, bricks and concrete are used, but they are still buildings of extremely low quality. Low-quality construction is just one of the problems, and with slum housing, a second is the lack of municipal services, sewage, waste collection, access to water, roads, or even fresh air. Even in the slightly better slums of South America, water and electricity are scarce and rationed. The exact description of slums in different areas of the world and cities is not an easy task, requiring extensive research. A synthetic summary of the living conditions and social problems in slums was made by

L. Driedger (1991), who characterised them as showing:

- weak educational base (lack of qualified teachers, teaching aids)

- high unemployment (low level of education and qualifications)

- high dependency on welfare (health, food)

- lack of a sense of community (transient; ethnic and racial diversity)

- family problems (high percentage of divorce, separation)

- personal degradation (alcoholism, drugs)

- high crime rate (theft, violence)

- numerous criminal gangs (anti-social and aggressive behaviour) 
Photo 1. Mumbai, slum laundry, building contrast

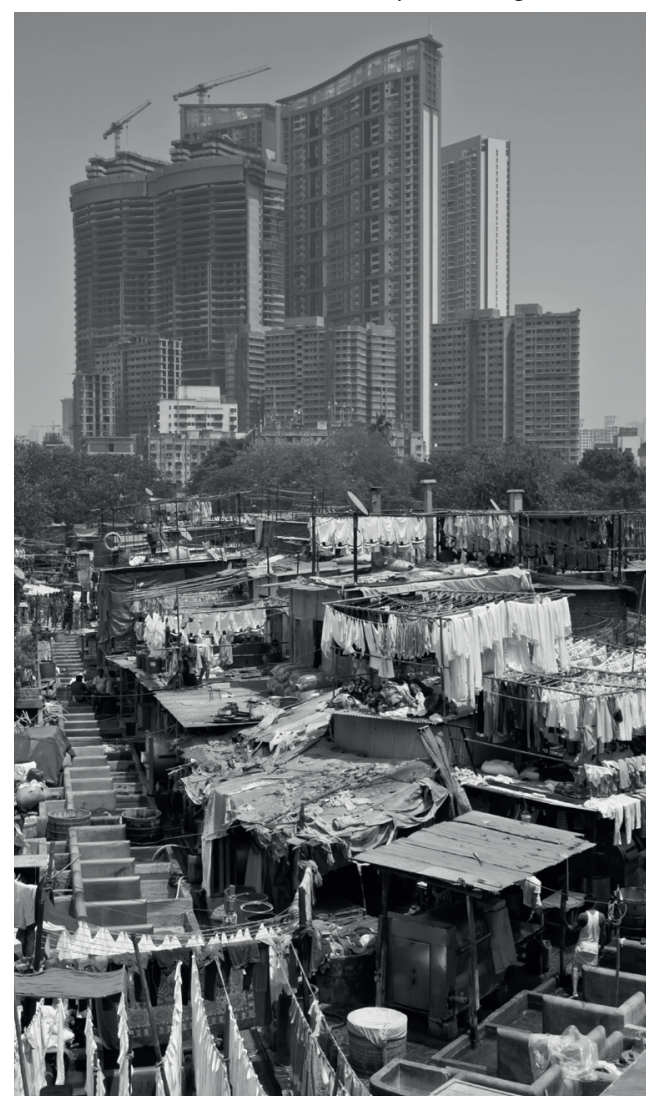

Source: Jensie De Gheest z Pixabay, downloaded under Creative Commons Zero-CC0 license

- political base (gang leaders, politicians)

- numerous religious sects (churches, new religions).

Based on the above list, it is difficult to find any positive social or economic phenomena in the slums. Besides, they are a huge ecological problem. For example, Indian cities are in the top 10 places in the world ranking of the most polluted in terms of air quality. It is estimated that in 2030, 1 in 8 people on Earth will be living in slums or some other form of informal housing.

Slum dwellers constitute a substantial percentage of city dwellers in individual countries (Table 1). The largest slums include:

- Khayelitsha in Cape Town (South Africa) with 400,000

- Kibera in Nairobi (Kenya), 700,000

- Dharavi in Mumbai (India), 1,000,000

- Neza near Mexico City (Mexico) 1,200,000

- Orangi Town in Karachi (Pakistan), 2,400,000 (Habitat for Humanity, 2017).

It is worth adding to the list the famous Rocinha and Cidade de Deus (City of God) favelas in Rio de Janeiro (Brazil) with 70,000 and 40,000 residents, respectively. It is important to remember that in this city alone, there are about 1000 favelas. 


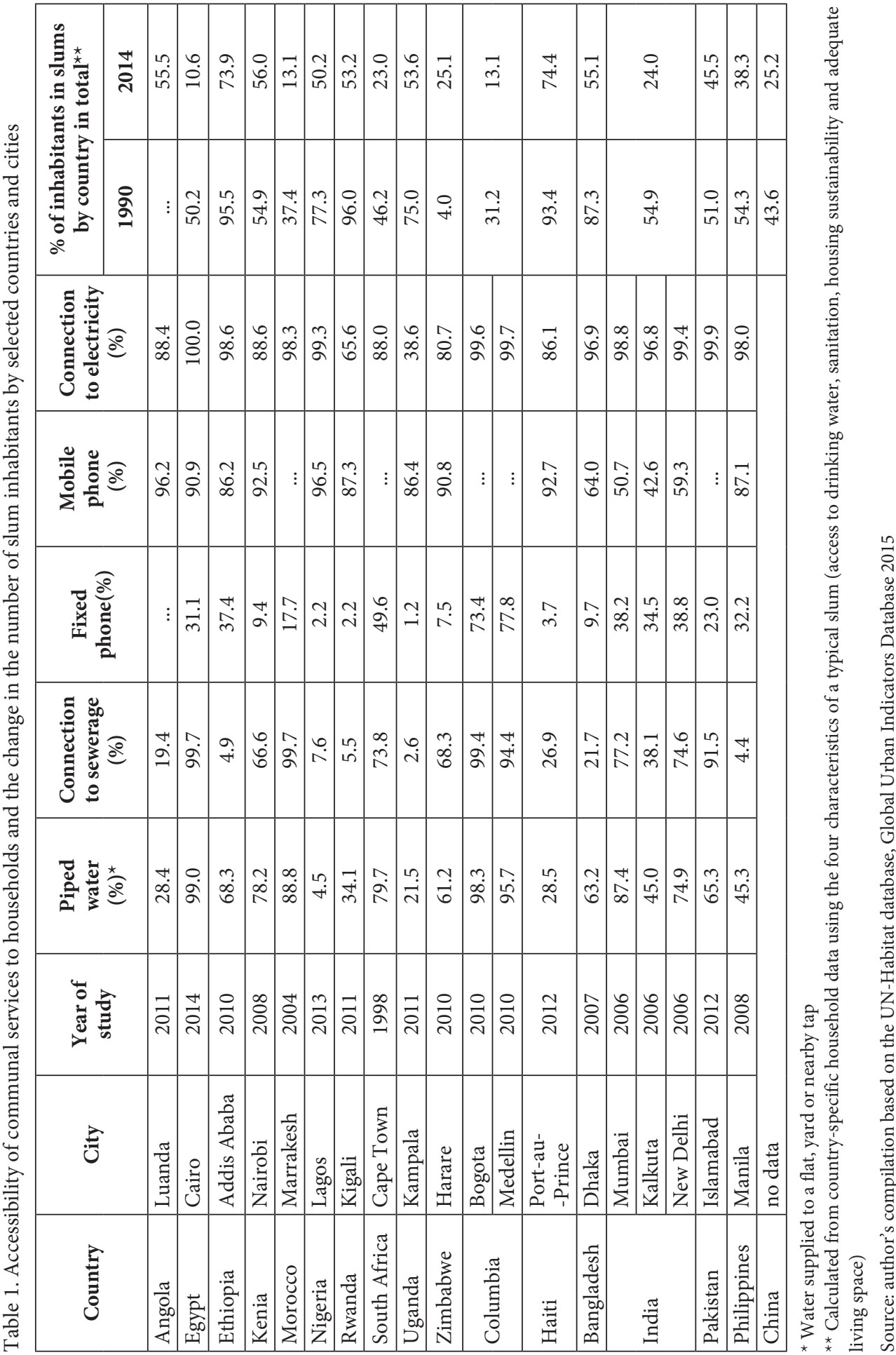


Over the years, the situation in the slums has been slowly improving. It has been possible thanks to the activities of the international community, social organisations, and the United Nations (UN-Habitat). The access of inhabitants to drinking water, electricity, waste disposal and mobile telephony is increasing, and Table 1 presents a comparison of selected data on the availability of municipal services for slum residents. The data come from different countries and different years, revealing significant scarcity and shortages in cities such as Lagos (Nigeria). There, as of 2013 , only $4.5 \%$ of slum households had access to tap water and $7.6 \%$ to sewage. However, an astonishing $99.3 \%$ of households had access to electricity and $96.5 \%$ to mobile telephony. In Kampala (Uganda), only $38 \%$ of slum residents had access to electricity, but $86 \%$ of households had access to mobile phones (2011).

The Colombian slums of Bogota and Medellin represent a completely different level in terms of access to communal services, resembling urban areas with standard development and communal services. Many changes have taken place in these cities, for example in Bogota due to Mayor Mockus and his successors. Thanks to the reforms, the living conditions in this city were significantly improved (McGuirk, 2015). The statistics presented in Table 1 do not reflect other non-measurable social and economic problems, as well as the issues of spatial chaos, exclusion of residents from decision-making or participation in deciding their fate and that of the districts in which they live.

\section{Informal urbanism against global urbanisation}

The number of cities where settlement without regulated legal status is observed, in particular the right to property, maintaining building standards, overpopulation and low living standards, is estimated on a global scale at 450. These cities are located in the Third World and developing BRICS countries (Brazil, India, China, South Africa), except Russia. They also appear in countries with a colonial past that have problems with indigenous (Amerindian) people, e.g. Argentina, Paraguay, Mexico and Chile (De la Jara, 2018). Since the slum phenomenon concerns many countries of the so-called Global South, the statistics use combined areas on individual continents, in this article called macro-aggregations. These are East Asia (with China), South Asia, South America and the Caribbean (there are, for example, numerous slums in Jamaica, Haiti), Subsaharan Africa (most of Africa with South Africa), South-East Asia, West Asia (including Arab countries, Israel, Cyprus, Turkey and Iran), North Africa (with Mauritania, Sudan, Chad and Somalia). Oceania was also added to this group. In the countries mentioned above, there has been an extremely dynamic increase in the urban population in the years 1990-2014. In 2014, the total number of urban inhabitants was 2.97 billion, which was a $99 \%$ increase from 1990. The highest increase in urban population was noted in West Asia: from 54 million in 1990 to 151 million in 2014. A slightly lower change applied to Subsaharan Africa $170 \%$, from approximately 133 million in 1990 to 359 million in 2014. In South-East Asia, the increase was $110 \%$ to nearly 300 million. For East Asia, the change was $106 \%$; in absolute numbers, it grew from 467 million to 960 million. For South Asia, for 1990-2014 it was 93\%. Smaller changes were recorded for South America (58\%), North Africa (51\%) and Oceania (55\%). Detailed data are presented in Figure 2.

The supplement to Figure 2 is a 'box and whiskers' plot in Figure 3. The individual years of observation for a given sub-area (macro-aggregation) were separated into columns, making it possible to compare the level of urbanisation and its change over time. 
Figure 2. Urban population in developing countries by macro-aggregation

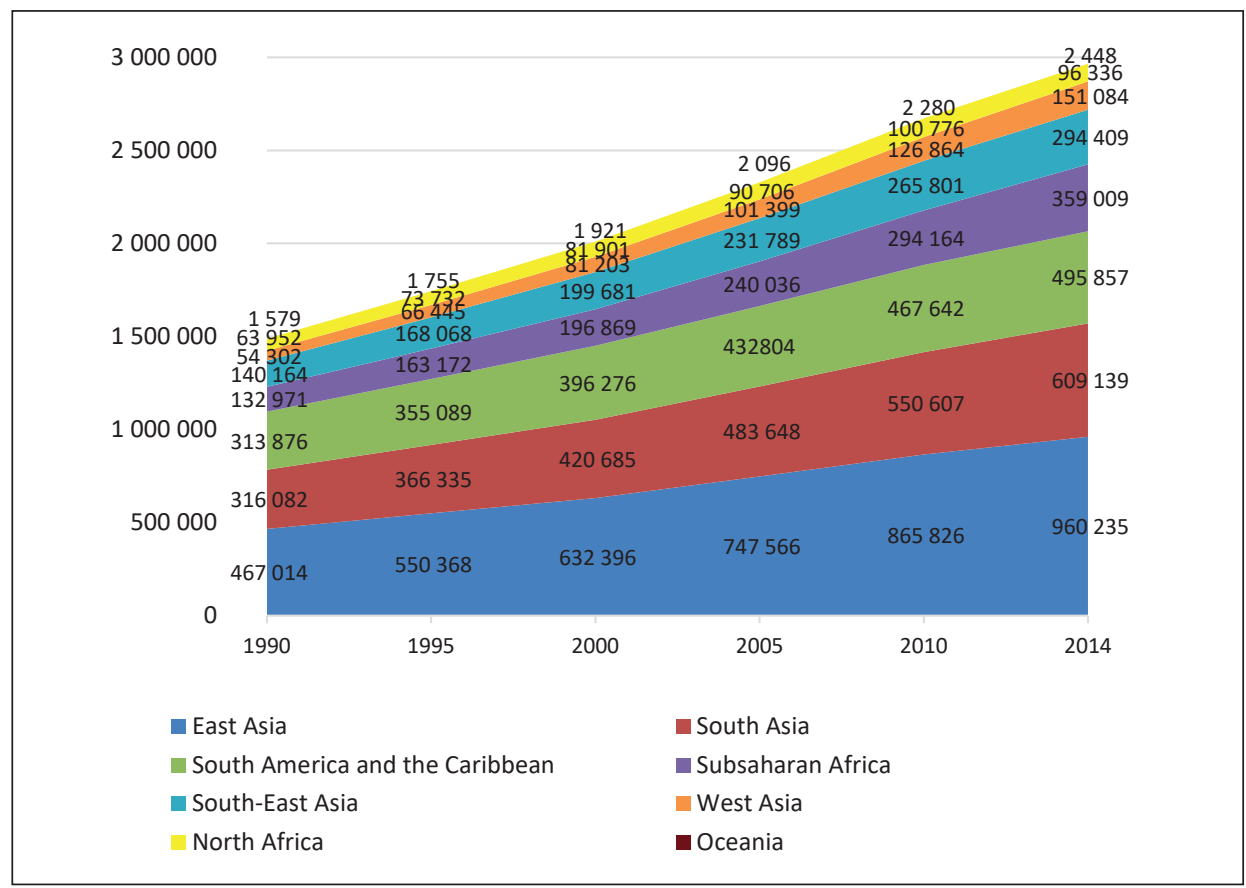

Source: author's compilation based on the UN-Habitat database

In 1990-2014, the number of urban residents among the total population increased in all aggregations except Oceania. The highest growths in an urban population can be observed in East Asia (from 33\% to 58\%) and South-East Asia (from 31.7\% to 47\%). The most urbanised continent is South America, where the level of urbanisation reaches $80 \%$ (an increase from 70\%). West Asia is also an area of high urbanisation with $70 \%$ (an increase from $61 \%$ ) whereas a figure above $50 \%$ is recorded in North Africa.

Against the dynamically changing number of the urban population presented above, the number of slum inhabitants is different. According to the data presented in Figure 4, there is a noticeable difference in individual macro-aggregations. The most significant number of slum inhabitants live in East Asian cities (mainly China) 251.6 million which has remained stable since 2005, after an increase from 200 million in 1990. Slum areas in South Asia were inhabited by 190 million people in 2014 which has been decreasing since 2005 and is approaching the level previously observed in 1990 of 180 million. We can see a sharp increase in the slum population of Subsaharan Africa, a figure that increased from 93 million in 1990 to 200 million in 2014, i.e. $115 \%$. However, this is not the most significant percentage increase as for West Asia, it was 205\% (from a low base level); it was an increase from 12.3 million in 1990 to 37.5 million in 2014. Besides, the number of slum inhabitants does not increase and is even declining, for instance, in North Africa, it has decreased from 22 million to 11.4 million, and in South America from 106 to 104 million. 
Figure 3. The proportion of the urban population for developing countries [\%] 1990-2015 (box-and-whiskers plot)

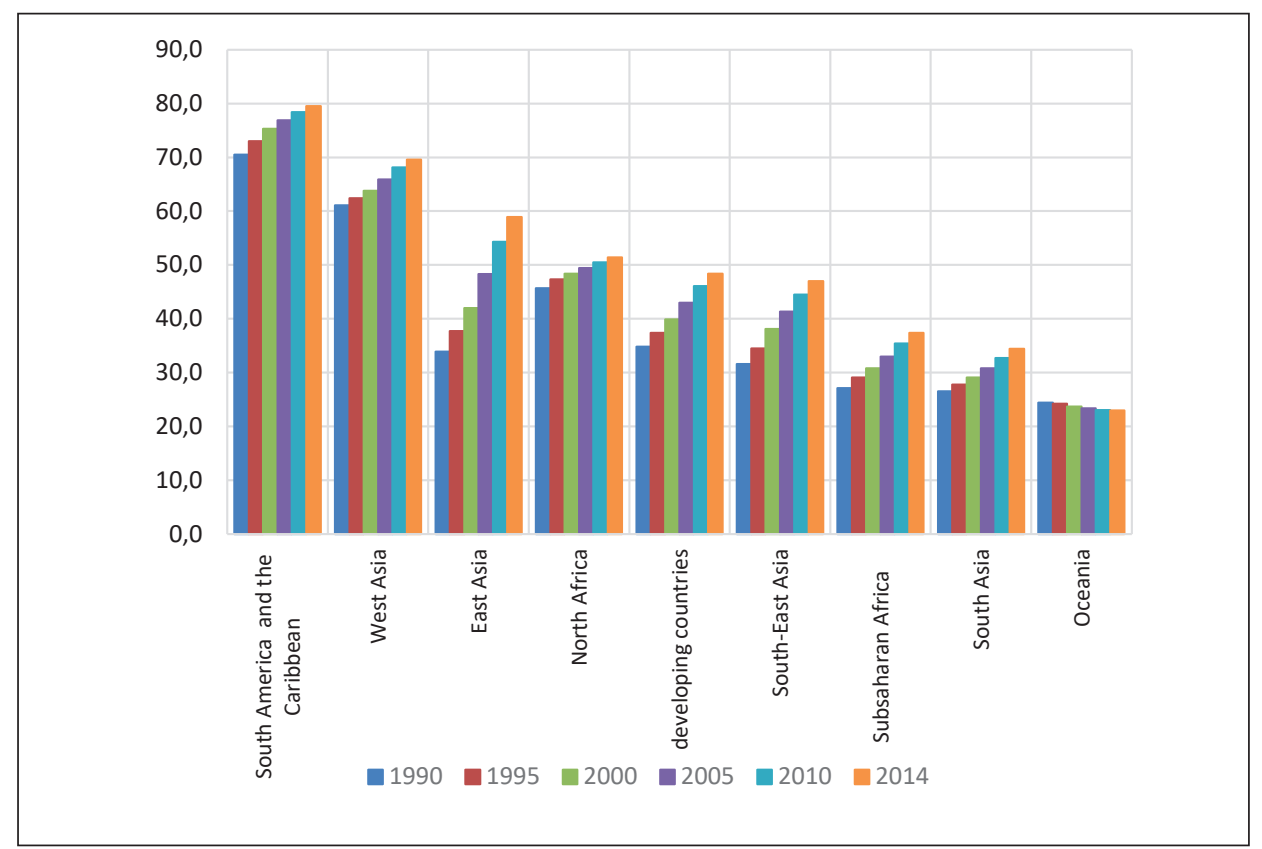

Source: author's compilation based on the UN-Habitat database

Figure 4. Number of slum inhabitants in thousands ('000) by macro-agglomeration of developing countries

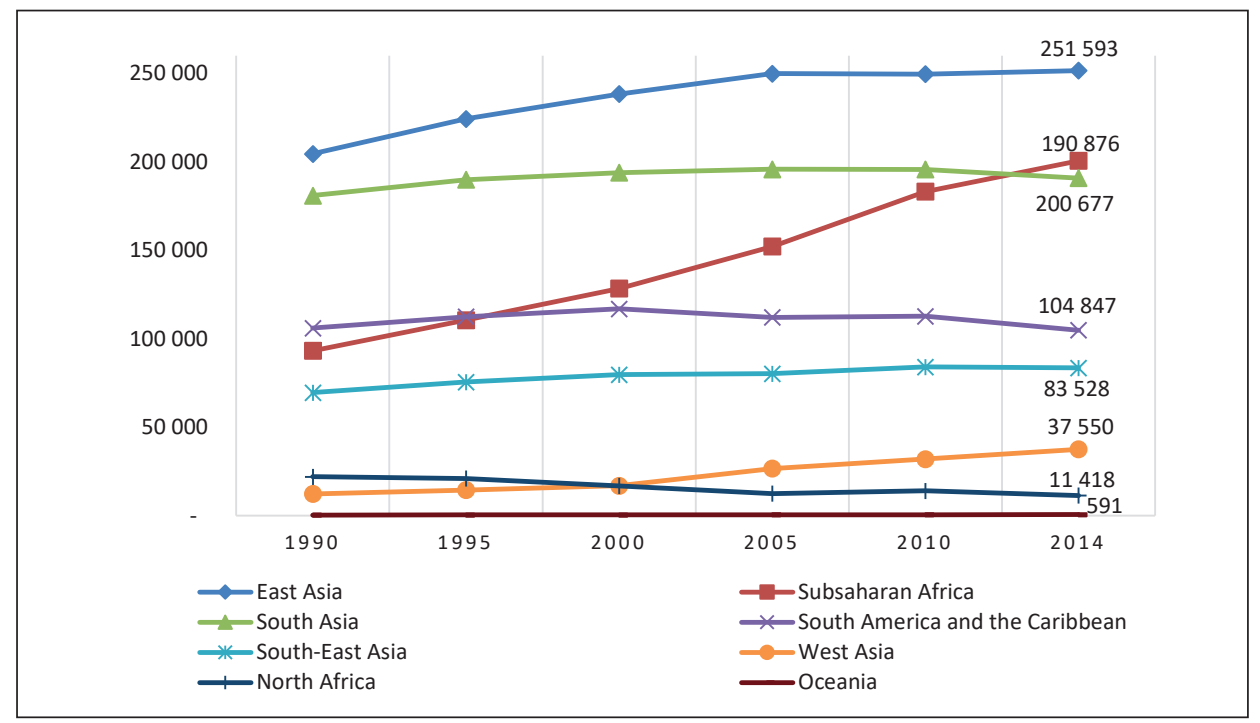

Source: author's compilation based on the UN-Habitat database 
Figure 5. The percentage share of the urban population in developing countries living in slums: 1990-2014

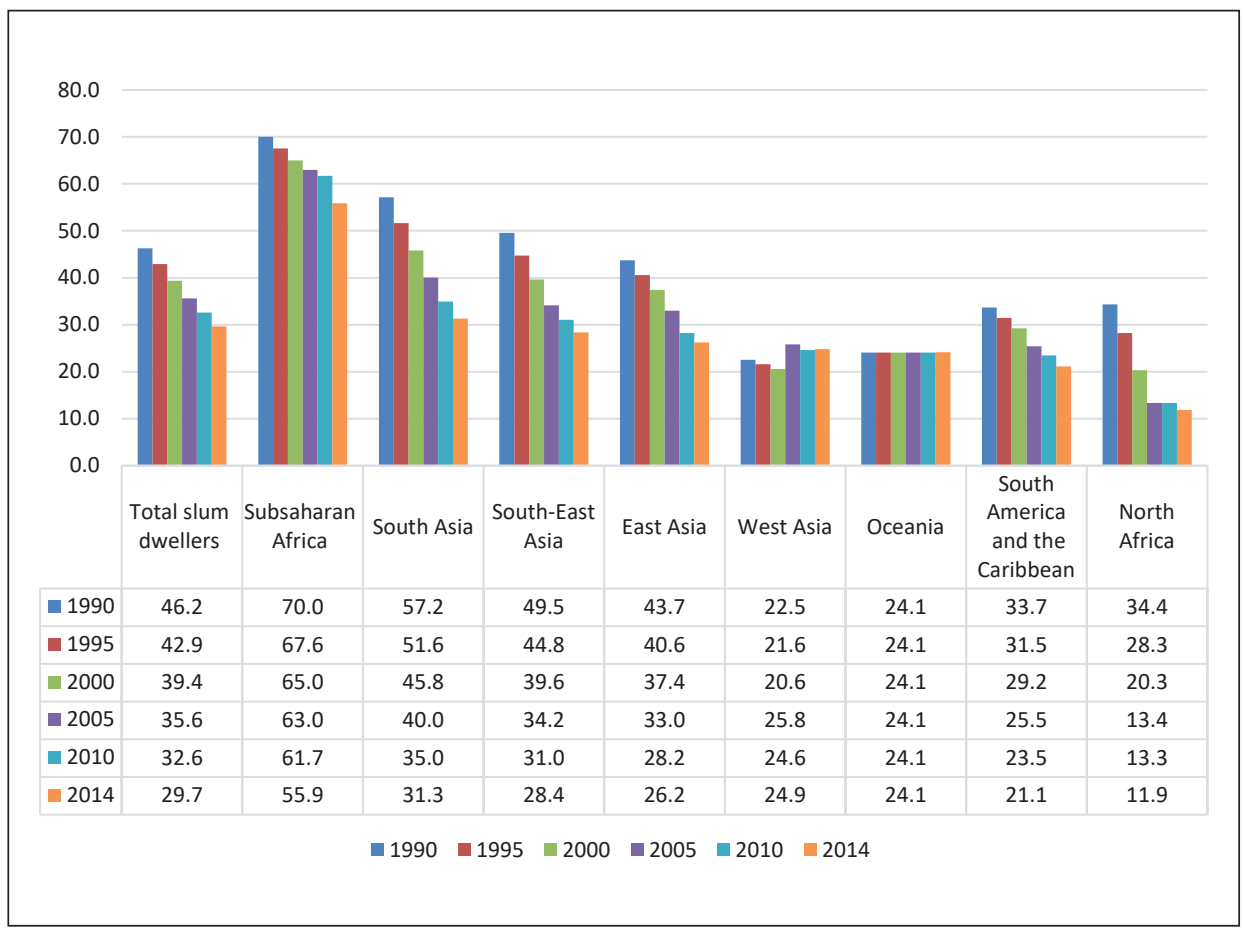

Source: author's compilation based on the UN-Habitat database

The data presented in Figure 4 shows, in several cases, a decline in the growth of the number of slum inhabitants, which means a change in its pattern. On the one hand, urban populations, and the urbanisation rate, is growing dynamically. On the other hand, the increase in the number of slum inhabitants, with few exceptions, is losing momentum. A natural step, in this case, will be to check the share of the population living in slums against the number of city inhabitants according to macro-aggregation. In order to make such a comparison possible, a graph was prepared (Figure 5). Its data shows a decline in the share of slum dwellers except for West Asia (an increase from 22.5 to 24.9\%) and Oceania (the same share of 24.1\%) throughout the measurement period. This promising trend is disrupted by the still high share of slum dwellers in Subsaharan African cities of $56 \%$. To sum up, the share of the population living in slums among the urban population in developing countries in 2014 was $29.7 \%$, which means since 1990 it had decreased by 16.6 percentage points.

Analysis of the percentage of slum inhabitants in the total urban population in 19902014 by individual aggregates showed that the most significant changes took place in South Asia (-25.8\%) and North Africa (-22.5\%). In 2014, North Africa had the lowest proportion living in slums in the entire ranking at $11.9 \%$. 
The entrepreneurship of slum dwellers - case studies

\section{Wakaliwood: the cinematic dream of a Ugandan slum}

The first example concerns African cinematography, known in Uganda as Ugiwood and in Nigeria, Nollywood. Wakaliwood is part of this phenomenon, on a slightly smaller scale. This name comes from the slum in the Ugandan capital, Kampala. In 2005, Isaac Nabwana, a young man who grew up during the brutal Idi Amin regime which took 500,000 lives, started his business. Isaac was always attracted to Western movies he had not watched but known from his brother's descriptions.

Wakaliwood is located in one of Wakaliga's most flood-prone areas. Nabwana and his wife, Harriet, share a bedroom with their three children, and their in-laws live in the other rooms. There is no running water, and power cuts are frequent. Isaac built the house himself, using hand-made bricks. Next to the modest house, there is also a rehearsal area, a recording studio, four back rooms for tenants and a small hut for props and scrap. Low-budget films are made using household items such as pans and PVC pipes which the filmmakers use, for example, to make fake rocket launchers. Most of the actors in the movies come from the slums, and the cast consists of relatives, friends and neighbours. Actors are not remunerated but receive a margin on DVD sales and can count on a roof over their heads in the rehearsal room which is used to practice dialogue during the day. Isaac's wife sells copies of movies at the local bazaar.

In 2011, A. Hofmanis, a film director, launched a crowdfunding campaign on social media for Isaac's film Ebola; he raised USD 13,000. For this amount, Isaac could buy generators, projectors and hard drives and the average budget for a new movie is USD 200. Mainly action movies are shot, and the dream of Isaac and others like him have made the film industry flourish in a country with only two production companies in 2008 while today there are over 500. M. Kasekende is a kung fu trainer who organises free training for children aged 7-13 who want to play a role in the Wakaliwood movies and at the moment thirteen children are attending his lessons. He is also an actor and the main character of the last film by Isaac Nabwana, entitled Bruce U (Schirato, 2018; Venema, 2015).

\section{Slumming - slum tourism}

The Oxford English Dictionary dates the first use of the word slumming to 1884. In London, slum areas such as Whitechapel and Shoreditch were visited to observe life there while wealthier people in New York City began visiting Bowery and Five Points on the Lower East Side, the neighbourhoods of poor immigrants. In the 1980s, black residents in South Africa organised city tours to educate white local officials about the lives of the country's black population. Such tours had become attractive to foreign tourists who wanted to learn more about apartheid.

In the 1990s, international tours of the most neglected areas of cities in developing countries began to be organised and are becoming increasingly popular and often run by professional companies. For example, Cape Town's slums are visited by over 300,000 tourists each year. A pop culture event, the acclaimed 2008 film Slumdog Millionaire, made the slums of Mumbai appear among the 'tourist attractions' of the city. The concept of slum tourism has recently started to gain more and more attention from both the media 
and academia and in December 2010, Bristol hosted the first international conference on slum tourism. A social network of people working in or related to slum tourism has been established, and the directions of slumming include favelas in Brazil and Dharavi in India.

Tourists in the slums are looking for a thrill, similar to stalking. Slums are areas that are interesting for their inhabitants' changeability, diversity, mystery and freedom. In this context, freedom means a different approach to law enforcement and drug use. In the slums, tourists will encounter specific subcultures in the form of graffiti, while artists and rebels often inhabit them. Slumming is developing so effectively that the Airbnb website offers apartments for rent in many slums around the world. The advantage of some is their location and scenic value, e.g. barrios in Caracas or Medellin with guiding services provided by slum dwellers, ensuring safety. In Rio de Janeiro, there has been a situation where residents paint their houses in different colours, encouraging tourists to use their cameras. Tourism in slums is controversial. Many slum dwellers are indifferent, for some, it allows economic activity and earnings. On the other hand, watching someone's poverty and forced lifestyle is sometimes called a 'human zoo' (source: Gutowska, 2015; Ma, 2010).

\section{'Picha Marangi' or colourful photos}

Stephen Okoth is a photographer, stylist and entrepreneur, leader of the Picha Marangi initiative (in Swahili the term means colourful photos). He looks like a colourful picture against the slums in which he lives. This 25-year-old was born and raised in the Kibera district of Nairobi, Kenya and says rather than a story of poverty and deprivation he wants to present a different picture. According to his account, as he grew up seeing the world of drugs and crime, he was determined to do something else, he wanted to stand out. He noticed that bright and colourful clothes contrasted well with his dark skin. Most people in Kibera accept his appearance and tell him that he has a unique style. Stephen purchases his clothes at the huge Gikomba market in Nairobi, where second-hand clothes imported from Europe and the United States are sold at hundreds of stalls. Stephen tries to wear a different outfit every day.

What Stephen does is similar to what a group of dwellers of another slum do, the Gentlemen of Bacongo. These are slum dwellers of Brazzaville in the Democratic Republic of Congo who dress in a sapeur or dandy style. Sappers belong to the Société des Ambianceurs et des Personnes Élégantes, or La SAPE (Society of Ambiance-Makers and Elegant People), one of the most exclusive clubs in the world. Members have their code of honour as the Gentlemen of Bacongo have become famous as photos of stylists from Africa have circulated the world. There were several exhibitions of their creations, and they have appeared on the covers of Vogue, while Paco Raban was inspired by their style when creating his fashion collection (Kenyan fashionista dares to stand out in Kibera slum, 2017; a Facebook profile of Picha Marangi et al.)

\section{The Tupac Amaru social movement}

Latin America is the birthplace of many grassroots movements, social rebellions and ideas. It was possible thanks to those who started to create social policy outside of neo-liberal patterns and to oppose corrupt governments and lawlessness. The Tupac Amaru social movement was founded in Argentina in the province of Jujuy; its full name is 
Organización Barrial Túpac Amaru (Tupac Amaru Neighborhood Organisation). The name and symbolism of the movement come from Tupac Amaru II, whose ancestor was Tupac Amaru - king of the Incas, beheaded by the conquistadors in 1571. Two hundred years after the death of Tupac Amaru, his name was taken by his descendant José Gabriel Condorcanqui who, as Tupac Amaru II, also led an anti-Spanish uprising and paid for it with his life. The organisation is also identified with other historical figures, the Argentinians Ernesto Che Guevara and Evita Perón. The key figure of the movement that emerged in San Salvador, the capital of the province of Jujuy, is its founder and leader, Milagro Sala, an indigenous Amerindian of the Kolla tribe.

The Tupac Amaru Movement is represented in 15 of Argentina's 23 provinces and has approximately 150,000 members. The movement's success and growing popularity are due to its charitable and collective work with the greatest being the construction of several housing estates for slum dwellers. These housing initiatives turned out to be cheaper than those carried out by developers applying for government subsidies and was achieved through the involvement and work of those interested in living on these estates and the movements' metalworking plants and brickworks supported the construction process. The movement deals with the provision of services such as health care and education (tutoring system, the purchase of a computer tomograph), feeding children ('a glass of milk'), and development of labour cooperatives in areas such as the textile and metallurgical industries, while managing public programs such as food distribution and legal advice. In the housing estates, sports centres with swimming pools, health centres and schools of various levels were established. Tupac Amaru owes its success to a working model based on cooperation, solidarity and democratic decision-making.

Milagro Sala, the founder of the left-wing Tupac Amaru movement, was repeatedly attacked and slandered by provincial governments and Argentinean politicians for her political ambitions. In 2012, the Tupac Amaru general assembly announced the creation of the People's Sovereignty Party, in 2013, Milagro Sala was elected as a member of the provincial parliament, and in 2015 as a member of Parlasur, the advisory body of South America's Mercosur trade bloc. In 2019, Milagro Sala, after several years in detention, was sentenced to 13 years in prison on charges of defamation and embezzlement. Social organisations, including Amnesty International and supporters of the movement, are fighting for her release (Tupac Amaru movement website; McGuirk, 2015).

\section{Dharavi - slum or economic zone?}

The famous Dharavi slum in Mumbai has a population of approximately one million covering $210 \mathrm{ha}$, and the slum has been in existence for 140 years. According to estimates, the slum inhabitants generate around USD 1 billion in turnover annually. This city within a city is an integral part of Mumbai's economy, and some voices claim that it could not function without it. Despite the crowds and typical slum buildings, their interiors are not stagnant or lazy. Carpenters assembling furniture can be seen there on the ground floor, and men on the first floor are laboriously cutting and sewing jeans. Next to them, workers crouching over sewing machines sew blouses, and other men's suits and wedding clothes. There are four companies in one sleepy shack and 60,000 of them in Dharavi.

Besides the ceramic and textile industries, garbage from many parts of the city is processed in the slums. As many 200,000 are estimated to be engaged in it. From Dharavi, 
products are exported not only to Mumbai or other parts of India but to the whole world. In addition to leather and textiles, jewellery and colourful sweets, various everyday accessories are produced here. Slum dwellers try to live a regular life; they have access to electricity and gas in cylinders, but sanitary and health conditions are at an elementary level.

According to a slum resident named Mobin, whose family owns several companies there, "Dharavi is a parallel economy"; "most developed countries have only one economy; however, India has two". India is a growing economic power, even if a considerable part of its economy operates in the shadows. India's informal economy is made up of hundreds of millions of shopkeepers, farmers, construction workers, taxi drivers, street vendors, rag pickers, tailors, repairers, go-betweens and many more.

This division exists in other developing countries, but in India, the scale is enormous. Experts estimate that the informal sector is responsible for most of India's annual economic growth and as much as $90 \%$ of all employment. Over the years, the Indian government has tried to increase industrial production with varying success, creating special economic zones to attract investors. Dharavi, by contrast, can be called a self-made special economic zone for the poor which is the result of the severe social inequality and failure of policymakers who are unable to accept millions of migrants from rural areas. Plans to transform Dharavi into a 'normal' neighbourhood sparked a debate about what Mumbai gains and what it would lose.

Figuratively, the Dharavi slums can be described (Vradley, 2011) as consisting of four floors like some houses built there: misfortune on the ground floor, work on the floor above, the third floor is politics, while hope is at the top (Vardley, 2011; further info Werner, 2017).

\section{Summary and conclusions}

The first part of the article discussed the nature of slums and who their inhabitants are. It showed a large variety of spatial forms, the poverty of their inhabitants and their exclusion from urban life due to the lack of ownership of their homes. It also indicated related shortages in infrastructure, organisation and spatial order, and hindered access to education and capital. When talking about the distribution and phenomenon of informal urbanism, they are treated as historical in developed countries, while those in developing countries are a modern-day issue. For this reason, they should be considered a transitional stage, an effect of socio-economic imbalance in the development process. However, in the post-colonial world, slums are established urban structures. The international community and UN-Habitat programs, such as Participatory Slum Upgrading Program (cf. UN-Habitat, 2017), have recorded some successes in achieving the UN Millennium Development and Sustainable Development Goals, but we cannot speak of complete success. Urbanisation is closely related to development; slum dwellers will remain on the margins of these changes unless they become full-fledged city dwellers, covered by the planning and effects of financing urban infrastructure.

In the second part, the number of slum dwellers was shown to have increased between 1990 and 2014, mainly in Subsaharan Africa and West Asia. Nevertheless, against the dynamic urbanisation, their overall share in macro-aggregations is decreasing. This situation gives moderate hope that the polarisation of economic development as manifested by the emergence of megacities will benefit slum dwellers, and more prosperous city dwellers 
will 'share' their income through redistribution. City authorities will include their problems in their election and reform programs (e.g. in Colombia).

In the third part, selected case studies were used to try to change the stereotype of stagnation dominating the slums. Slums prove that entrepreneurship can exist even in conditions of scarcity, lack of capital, knowledge and qualifications, and the institutions that could trigger it. In a way, it is triggered by extreme poverty and the need to deal with deprivation and living conditions. One of the manifestations of entrepreneurship is creativity which has appeared among the heroes of the Wakaliwood case study and the Colourful Picture of 'Picha Marangi'. In both cases, technological changes on a global scale were significant as they allowed slum inhabitants to contact the world, Western pop culture and fundraising. The controversial slumming tourism also brings benefits to the inhabitants and online platforms, such as Airbnb, have made it possible to earn money from it. The Tupac Amaru case study shows that the empowerment and self-esteem of poor people, along with a smart investment policy, works well exposing the ineffective mechanisms of government aid in developing countries. However, it is disturbing when quoting Karl Marx from earlier in the article about slum dwellers being a 'surplus army' and with the training of leaders and grassroots activities outside the structures of power seen as a political threat. The Dharavi slums in Mumbai, based on the articles cited, seem to be a victim of their entrepreneurship, as the cheap labour force serving rich castes in India is, despite its economic potential and dynamism, kept within the confines of an informal economy and low labour costs.

The selected examples are a premise for the general conclusion that the use of topdown, planned heteronomous solutions brings worse results in the fight against poverty and slums. Examples include large-scale social housing programs and their failures in, for example, Mexico; police battles against gangs in Brazil; a lack of understanding of residents' needs; exploitation under the guise of creating jobs, and dependence on aid perpetuating helplessness. The opposite is to operate autonomously. Slum dwellers receive funding and support, not for everything they do, but their creativity and diligence are triggered. They are treated as a resource with a defined potential for self-repair, not a burden and a problem. This more difficult way requires research, experimentation, listening, paying more attention to the needs of slum inhabitants and integrity on the part of national and local governments.

\section{References}

Angotti, T. (2006). Apocalyptic anti urbanism: Mike Davis and his planet of slums. International Journal of Urban and Regional Research, 30(4), 961-967.

Davis, M. (2006). Planet of slums. London: Verso.

De la Jara, A. (2018; 2029, 10 November). Slums on the rise in Chile. Reuters. Retrieved from: https:// www.reuters.com/article/us-chile-migrants/slums-on-the-rise-in-chile-idUSKCN1OP1DJ

Censo Demográfico 2010. Aglomerados subnormais:Primeiros resultados. (2011). Rio de Janeiro: IBGE, $201,1$.

Driedger, L. (1991). The Urban Factor. New York: Oxford University Press.

Friesen, J., Taubenböck, H., Wurm, M., Pelz, F.P. (2019). Size distributions of slums across the globe using different data and classification methods. European Journal of Remote Sensing, 52(2), 99-111. doi: 10.1080/22797254.2019.1579617 
Gregory, D., Johnston, R., Pratt, G., Watts, M., Whatmore, S. (2009). The Dictionary of Human Geography. Now York: Wiley-Blackwell.

Gutowska, A. (2015). Going beyond poverty tourism? The narratives of Kibera residents and their meanings constructed within the frame of slum tours. Folia Turistica, 37, 85-99.

Habitat for Humanity Great Britan. (2017; 2019, 10 November). Retrieved from: https://www.habitatforhumanity.org.uk/blog/2017/12/the-worlds-largest-slums-dharavi-kibera-khayelitsha-neza/

Harvey, D. (2012). Bunt miast. Prawo do miasta i miejska rewolucja. Warszawa: Fundacja Bęc Zmiana.

Kenyan fashionista dares to stand out in Kibera slum. (2017; 2019, 10 November). Retrieved from: https:// www.bbc.com/news/world-africa-40012435.

Driedger, L. (1991). Czynnik miejski, Nowy Jork: Oxford University Press.

Ma, B. (2010; 2019, 10 November). A Trip into the Controversy: A Study of SlumTourism Travel Motivations. University of Pennsylvania Scholarly Commons Undergraduate Humanities. Retrieved from: http://repository.upenn.edu/cgi/viewcontent.cgi?article=1011\&context=uhf_2010

McGuirk, J. (2015). Radykalne miasta. Przez Amerykę Lacińską w poszukiwaniu nowej architektury. Warszawa: Fundacja Bęc Zmiana.

Najbardziej zanieczyszczone miasta świata. (2019, 15 October). Retrieved from: http://wgospodarce.pl/ informacje/60828-oto-najbardziej-zanieczyszczone-miasta-swiata

Schirato. S. (2018). Wakaliwood: The cinematic dream of a Uganda slum. Retrieved from: https://www. aljazeera.com/indepth/inpictures/wakaliwood-cinematic-dream-uganda-slum-180305080922395. html

Small, J., Ross, S., Witherick, M. (2001). A Modern Dictionary of Geography. London: Arnold.

Tupac Amaru. (2019, 15 October). Retrieved from: https://www.welcometothecantri.com/en/ la-tupac-amaru/

Understanding Slums: Case Studies for the Global Report on Human Settlements 2003. (2019, 15 October). Retrieved from: https://www.ucl.ac.uk/dpu-projects/Global_Report/home.htm

Venema, V. (2015). Uganda's Tarantino and his $\$ 200$ action movies. Retrieved from: https://www.bbc. com/news/magazine-32531558

Vradley, J. (2011; 2019, 15 October). In One Slum, Misery, Work, Politics and Hope. NY Times. Retrieved from: https://www.nytimes.com/2011/12/29/world/asia/in-indian-slum-misery-work-politicsand-hope.html

UN-Habitat. (2016). Urbanization and Development: Emerging Futures. World Cities Report 2016. UNHabitat.

Werner, K. (2017; 2019, 15 October). Milionowy slums i turystyka slumsowa, czyli - chodź poogladajmy sobie biedę! Retrieved from: https://kolemsietoczy.pl/milionowy-slums-w-mumbaju-i-turystyka-slumsowa-czyli-chodz-poogladamy-sobie-biede/

Jacek Rudewicz, PhD, Eng. He is an assistant professor at the Institute of Spatial Management and Socio-Economic Geography University of Szczecin. He graduated in geography with a specialisation in socio-economic geography, management and marketing, and economics. In his academic work, he deals with urban studies, sustainable development, and regional development.

ORCID: https://orcid.org/0000-0002-2659-4754

\section{Address:}

Uniwersytet Szczeciński

Instytut Gospodarki Przestrzennej

i Geografii Społeczno-Ekonomicznej

ul. Mickiewicza 64

71-101 Szczecin, Polska

e-mail: jacek.rudewicz@usz.edu.pl 